\title{
PENETAPAN HUTAN LINDUNG GUNUNG CEREMAI MENJADI TAMAN NASIONAL DAN DAMPAKNYA BAGI MASYARAKAT SEKITAR KAWASAN
}

\author{
(The Decision of Converting Ceremai Protection Forest to Become \\ Ceremai National Park and its Impact on the Surounding Community)
}

\author{
Oleh/By:
}

Iis Alviya ${ }^{1)}$

\begin{abstract}
Based on the Minister of Forestry decision, protection forest in Ceremai Mountain ( \pm 15.000 ha) located in Kuningan and Majalengke Districts converted to become national park. The reasons are: (1) Ceremai Mountain forest is representative of mountain forestecosystem which is still natural, (2) Ceremai Mountain forest has important bydrology function and sources of germ plasma, and (3) Ceremai Mountain forest has unique flora and fauna.

For the communities around Mountain Ceremai, the government policy gives negative impact because the accessibility to the forest is limited. The role of national park as preserving of flora and fauna biodiversity and the sustainability of utilization of natural resources and ecosystem influences not only for local communities but also for most of the Indonesia communities and their environment.

To achieve the optimal function of national park, it requires (1) effective management of nationalpark, (2) sufficient and qualified human resources, (3) good approach to the communities around the national park, and (4) increasing public awareness in national park sustainability.
\end{abstract}

Key words: Protection forest, nationalpark, and Ceremai Mountain

\begin{abstract}
ABSTRAK
Berdasarkan Keputusan Menteri Kehutanan, hutan lindung pada kelompok hutan Gunung Ceremai seluas 15.000 ha yang terletak di Kabupaten Kuningan dan Kabupaten Majalengka, Propinsi Jawa Barat berubah fungsi menjadi Taman Nasional. Alasannya adalah (1) kawasan hutan Gunung Ceremai ini merupakan keterwakilan tipe ekosistem hutan pegunungan yang masih asli, (2) mempunyai fungsi hidrologis dan sumber plasma nutfah yang penting, dan (3) mempunyai habitat berbagai flora dan fauna yang khas.

Bagi masyarakat sekitar kawasan hutan Gunung Ceremai, kebijakan pemerintah tersebut terasa sangat merugikan, karena akses terhadap kawasan hutan menjadi sangat terbatas. Namun peranan taman nasional sebagai pengawetan keanekaragaman jenis tumbuhan dan satwa, serta pemanfaatan secara lestari sumberdaya alam hayati dan ekosistemnya berpengaruh besar bukan hanya bagi masyarakat lokal tapi bagi sebagian besar masyarakat Indonesia dan lingkungannya.

Untuk mencapai optimalisasi fungsi kawasan taman nasional maka harus terbentuk (1) pengelolaan taman nasional yang mantap, (2) kualitas SDM yang memadai, (3) pendekatan yang baik terhadap masyarakat sekitar kawasan, dan (4) membangun tingkat kesadaran masyarakat terhadap kelestarian sumberdaya alam taman nasional.
\end{abstract}

\footnotetext{
${ }^{1}$ Peneliti pada Pusat Penelitian Sosial Ekonomi dan Kebijakan Kehutanan, Bogor
} 


\section{Jumal Analisis Kedjizan Kehutanan Vd. 3Na 2, Juli 2006: 87-94}

Kata kunci: Hutan lindung, taman nasional, dan Gunung Ceremai

\section{PENDAHULUAN}

Berdasarkan Surat Keputusan Menteri Kehutanan No. 424/Menhut-II/2004, tentang hutan lindung pada kelompok hutan Gunung Ceremai seluas \pm 15.000 ha yang terletak di Kabupaten Kuningan dan Kabupaten Majalengka, Propinsi Jawa Barat berubah fungsi menjadi taman nasional.

Menurut Undang-undang No. 41 tahun 1999 tentang kehutanan yang dimaksud Hutan Lindung adalah kawasan hutan yang mempunyai fungsi pokok sebagai perlindungan sistem penyangga kehidupan, mengatur tata air, mencegah banjir, mengendalikan erosi, mencegah intrusi air laut, dan memelihara kesuburan tanah. Sedangkan yang dimaksud Taman Nasional adalah kawasan pelestarian alam yang mempunyai ekosistem asli, dikelola dengan sistem zonasi yang dimanfaatkan untuk tujuan penelitian, ilmu pengetahuan, pendidikan, menunjang budidaya, pariwisata dan rekreasi alam. Adapun fungsi kawasan taman nasional sebagai hutan pelestarian alam adalah sebagai perlindungan sistem penyangga kehidupan, pengawetan keanekaragaman jenis tumbuhan dan satwa, dan pemanfaatan secara lestari sumberdaya alam hayati dan ekosistemnya.

Jika dilihat berdasarkan fungsinya, baik kawasan hutan lindung maupun taman nasional mempunyai peranan yang sangat besar bagi keberlangsungan hidup manusia dan sumberdaya alam Indonesia. Namun jika dilihat dari segi pemanfaatan kawasan, hal ini kemungkinan berpengaruh besar terhadap keadaan sosial ekonomi masyarakat sekitar kawasan dan masyarakat di luar kawasan.

Tulisan ini bertujuan untuk memberikan gambaran mengenai dampak ditetapkannya hutan lindung pada kelompok hutan Gunung Ceremai menjadi taman nasional bagi masyarakat sekitar kawasan.

\section{GAMBARAN UMUM KAWASAN GUNUNG CEREMAI}

Gunung Ceremai yang merupakan gunung tertinggi di Propinsi Jawa Barat merupakan salah satu aset sumberdaya alam yang terdapat di Kabupaten Kuningan dan Kabupaten Majalengka. Kawasan Gunung Ceremai memiliki potensi sumberdaya alam yang melimpah, di antaranya sumberdaya hayati, sumberdaya lahan dan sumber mata air. Sedangkan fungsi kawasan Gunung Ceremai antara lain adalah sebagai (a) Wahana pendidikan, (b) Wahana pariwisata, (c) Kawasan resapan air (catchment area), (d) Kawasan penyangga (buffer area), (e) Sumber air, serta (f) Budidaya pertanian, kehutanan dan perkebunan.

Kawasan Gunung Ceremai mempunyai ketinggian sekitar $3.078 \mathrm{~m}$ di atas permukaan laut sehingga udara di kawasan tersebut sangat sejuk dengan curah hujan rata-rata per tahun 2.000 - $4.000 \mathrm{~mm}$ serta termasuk ke dalam iklim B dan C (klasifikasi Schmidt dan Ferguson, 1951). Gunung Ceremai merupakan gunung dalam klasifikasi magnetik tipe A (strato) atau masih aktif, beriklim udara sejuk (Anonim, 2005).

Kondisi topografi di kawasan ini berombak, berbukit hingga bergunung, mempunyai peranan yang sangat strategis dan merupakan salah satu aset dalam 
pembangunan yang sangat penting khususnya bagi 3 (tiga) kabupaten, yaitu Kabupaten Kuningan, Majalengka, dan Kabupaten/Kota Cirebon.

Gunung Ceremai merupakan salah satu ekosistem pegunungan yang memiliki keunikan, karena merupakan gunung yang letaknya tidak terlalu jauh dengan laut (Laut Jawa) dibandingkan dengan gunung-gunung lainnya di Pulau Jawa. Kawasan Gunung Ceremai merupakan daerah yang memiliki keanekaragaman hayati yang cukup tinggi baik flora maupun fauna yang sebagian di antaranya dilindungi oleh undang-undang.

Sumber mata air di Wilayah Gunung Ceremai berjumlah 149 buah, terdiri dari 147 buah mata air yang mengalir selama 6 bulan dalam setahun dan 2 buah mata air yang mengalir selama 3 bulan dalam setahun. Selain itu, beberapa sumber air yang dapat digunakan untuk irigasi dan kegiatan pariwisata di antaranya adalah Waduk Darma, Darmaloka, Balong Cigugur, Balong Dalem, dan Telaga Remis. Berdasarkan penelitian Bappeda Kuningan-LSM Rissapel Kuningan tahun 2000, Potensi air di wilayah Gunung Ceremai yang dimanfaatkan untuk industri dan perekonomian lainnya di wilayah Cirebon adalah:

1. Debit air untuk Perusahaan Daerah Air Minum (PDAM) Kabupaten Cirebon sebesar 200 liter/detik dan untuk PDAM Kota Cirebon sebanyak 800 liter/detik.

2. Suplai air untuk Pertamina Cirebon sebesar 50 liter/detik.

3. Suplai air untuk pabrik semen PT Indocement Cirebon sebesar 36 liter/detik.

4. Suplai air untuk kegiatan pertanian, perkebunan tebu dan pabrik gula sebesar 2500 liter/detik.

Mata air yang terdapat di kawasan Gunung Ceremai pada umumnya merupakan mata air gravitasi karena aliran air tanah yang terpotong topografi dan keluar melalui celah dan rongga antara bukit pada bebatuan breksi gunung api (Anonim, 2005).

Hutan merupakan sumberdaya alam yang sangat potensial. Khusus untuk Kabupaten Kuningan luas hutan mencapai 46.333,15 ha atau 30\% dari luas wilayah Kuningan secara keseluruhan dengan tingkat kelestarian lingkungan yang masih terjaga. Potensi kayu yang dimiliki sebesar $51.613,254 \mathrm{~m}^{3}$. Jenis hutan yang terdapat di wilayah Kabupaten Kuningan dapat dilihat pada Tabel 1, dan jumlah produksi hasil hutan dapat dilihat pada Tabel 2.

\section{Tabel1. Jenis hutan di wilayah Kabupaten Kuningan}

\section{Table 1. Type offorest in Kuningan District}

\begin{tabular}{|l|l|c|}
\hline No & \multicolumn{1}{|c|}{$\begin{array}{c}\text { Jenis hutan } \\
\text { (Forest type) }\end{array}$} & $\begin{array}{c}\text { Luas } \\
\text { (Area), ha }\end{array}$ \\
\hline 1 & Hutan Produksi & $20.756,95$ \\
2 & Hutan Lindung & $15.043,20$ \\
3 & Hutan Wisata & 1.650 \\
4 & Hutan Rakyat dan Kebun Campuran & 8.883 \\
\hline & & \\
\hline
\end{tabular}

Sumber: Website: http//www.kuningan.go.id (2005) 
Tabel 2. Jumlah produksi hasil hutan Kabupaten Kuningan

Table 2. Number offorest product in Kuningan

\begin{tabular}{|l|l|l|}
\hline No & \multicolumn{1}{|c|}{$\begin{array}{c}\text { Jenis hasil } \\
\text { (Kind of product) }\end{array}$} & \multicolumn{1}{|c|}{$\begin{array}{c}\text { Jumlah per tahun } \\
\text { (Total per year) }\end{array}$} \\
\hline 1 & Kayu bulat & $4.150 \mathrm{~m}^{3}$ \\
2 & Kayu jati & $587 \mathrm{~m}^{3}$ \\
3 & Kayu pinus/rimba & $17.200 \mathrm{~m}^{3}$ \\
4 & Kayu rawa & $600 \mathrm{~m}^{3}$ \\
5 & Getah Pinus & $380,4 \mathrm{~kg}$ \\
6 & Rotan & $37.110 \mathrm{batang}$ \\
7 & Kopi & 133 ton \\
\hline \multicolumn{2}{|c|}{ Nilai produksi (Value) } & Rp 1.505 .818 .970 \\
\hline
\end{tabular}

Sumber: Website: http//www.kuningan.go.id

Kabupaten Majalengka memiliki luas hutan sekitar 48.444 ha. Hutan tersebut terdiri atas hutan negara seluas 20.140 ha, hutan rakyat 3.780 ha, dan kebun campuran 24.524 ha. Selain hutan, Kabupaten Majalengka memiliki lahan sawah seluas 50.937 ha yang meliputi irigasi teknis, setengah teknis, irigasi sederhana, dan tadah hujan (Anonim, 2004).

Potensi obyek wisata yang ada di Kabupaten Majalengka sangat beragam, diantaranya adalah wisata alam, tirta (telaga), argo, industri, seni dan budaya, ziarah, dan wisata olah raga. Pengembangan potensi obyek wisata tersebut tersebar di Kabupaten Majalengka bagian utara, tengah, dan selatan.

\section{ALASAN PENETAPAN KAWASAN HUTAN LINDUNG GUNUNG CEREMAI MENJADI TAMAN NASIONAL}

Menyusul telah ditetapkannya 4 taman nasional yaitu Batang Gadis (Sumut), Gunung Merapi (Jateng-DIY), Gunung Merbabu (Jateng) dan Tesso Nilo (Riau), Departemen Kehutanan saat ini menetapkan 12 kawasan konservasi lainnya untuk dijadikan taman nasional. Taman Nasional Gunung Ceremai adalah salah satu kawasan konservasi dari 12 kawasan tersebut. Upaya ini merupakan salah satu wujud dari lima kebijakan prioritas Departemen Kehutanan yaitu melakukan rehabilitasi dan konservasi sumberdaya hutan.

Pertimbangan pengusulan kawasan Gunung Ceremai untuk dijadikan taman nasional berdasarkan potensi yang ada adalah Kawasan Hutan Gunung Ceremai seluas 15.383 Ha ini merupakan keterwakilan tipe ekosistem hutan pegunungan yang masih asli dan kompak. Di samping mempunyai fungsi hidrologis dan sumber plasma nutfah yang penting, kawasan ini juga merupakan habitat berbagai flora dan fauna yang khas seperti: Saninten, Rasamala, Benda, Dadap, Paku-pakuan, Macan Kumbang, Surili, Elang Jawa, Kijang, Landak dan lain-lain.

Penunjukan kawasan konservasi baik kawasan pelestarian alam (Taman Nasional, Taman Hutan Raya, Taman Wisata Alam) dan kawasan suaka alam (Suaka Margasatwa, Cagar Alam) tersebut merupakan perwujudan kebijakan konservasi sumberdaya alam hayati dan ekosistemnya yang bertujuan untuk mengusahakan terwujudnya kelestarian sumberdaya alam hayati serta keseimbangan ekosistemnya. Keadaan demikian dapat lebih 
mendukung upaya peningkatan kesejahteraan masyarakat dan mutu kehidupan manusia dengan meningkatkan pengelolaan dan pembinaan populasi, jenis, genetik dan ekosistem di kawasan konservasi serta pengembangan wisata alam dan pemanfaatan jasa lingkungan (Handadhari, 2004).

\section{DAMPAK DITETAPKANNYA KAWASAN HUTAN LINDUNG MENJADI TAMAN NASIONAL}

Perubahan status kawasan hutan lindung menjadi taman nasional menyebabkan kewenangan system pengeloaan kawasan pun berubah. Menurut peraturan perundangan, kewenangan pengelolaan taman nasional berada di bawah pemerintah pusat melalui Balai Taman Nasional yang menyelenggarakan tugas dekonsentrasi. Hutan lindung berada di bawah kewenangan dinas kehutanan kabupaten dan propinsi. Dalam beberapa kasus penunjukan kawasan menjadi taman nasional, pemerintah daerah menuntut agar pemerintah pusat menyediakan kompensasi bagi pengelolaan kawasan ini karena kehilangan kesempatan memperoleh pendapatan. Hal ini terjadi karena kayu yang sangat potensial di dalam kawasan tersebut tidak dapat diambil untuk dijual.

Upaya pemerintah menetapkan suatu kawasan menjadi taman nasional seringkali ditentang masyarakat sekitar kawasan karena dianggap mengganggu kepentingan dan hajat hidup masyarakat lokal. Pemanfaatan kawasan pada taman nasional yang berdasarkan sistem zonasi dirasakan telah mempersempit akses mereka terhadap kawasan hutan.

Berdasarkan PP No. 34 tahun 1999, pemanfaatan pada hutan lindung dapat berupa: (i) pemanfaatan kawasan yang meliputi usaha budidaya tanaman obat, tanaman hias, jamur, perlebahan, penangkaran satwa liar, dan sarang burung wallet; (ii) pemanfaatan jasa lingkungan yang meliputi usaha wisata alam, olah raga tantangan, pemanfaatan air, dan perdagangan karbon; dan (iii) pemungutan hasil hutan bukan kayu seperti mengambil rotan, madu, buah, dan aneka hasil hutan lainnya

Pemanfaatan kawasan taman nasional menurut PP No. 68 tahun 1998 harus berdasarkan pada sistem zonasinya. Dalam UU No.41 Tahun 1999, taman nasional terdiri atas

a. Zona inti, yaitu bagian kawasan taman nasional yang mutlak dilindungi dan tidak diperbolehkan adanya perubahan apapun oleh aktivitas manusia. Zona inti dapat dimanfaatkan untuk keperluan penelitian dan pengembangan yang menunjang pemanfaatan, ilmu pengetahuan, pendidikan dan atau kegiatan penunjang budidaya.

b. Zona rimba, yaitu bagian taman nasional yang berfungsi sebagai penyangga zona inti. Zona rimba dapat dimanfaatkan untuk keperluan yang sama pada zona inti ditambah untuk wisata alam terbatas.

c. Zona pemanfaatan, yaitu bagian kawasan taman nasional yang dijadikan pusat rekreasi dan kunjungan wisata. Zona pemanfaatan dapat dimanfaatkan untuk hal sama seperti pada zona inti ditambah untuk keperluan pariwisata alam dan rekreasi. Berdasarkan uraian di atas terlihat bahwa pemanfaatan kawasan pada hutan lindung dapat dilakukan pada semua kawasan, sedangkan pada taman nasional pemanfaatan kawasan hanya dapat dilakukan pada zona pemanfaatan. Berdasarkan 


\section{J umal AnalisisKedijakanKehutanan Vo. 3No. 2, Jul 2006: 87-94}

kondisi fisik dan potensi sumberdaya alam yang terdapat pada kawasan hutan Gunung Ceremai, hal ini tentu sangat merugikan bagi masyarakat karena akses terhadap kawasan hutan menjadi sangat terbatas. Namun peranan Taman Nasional sebagai pengawetan keanekaragaman jenis tumbuhan dan satwa, serta pemanfaatan secara lestari sumberdaya alam hayati dan ekosistemnya berpengaruh besar bukan hanya bagi masyarakat lokal tapi bagi seluruh masyarakat Indonesia dan lingkungannya.

Hutan sebagai sumber daya nasional harus dimanfaatkan sebesar-besarnya bagi masyarakat dan tidak boleh terpusat pada seseorang, kelompok atau golongan tertentu. Oleh karena itu, pemanfaatan hutan harus didistribusikan secara berkeadilan melalui peningkatan peran serta masyarakat.

\section{BEBERAPA UPAYA TERWUJUDNYA PENGELOLAAN TAMAN NASIONAL YANG MANTAP}

Perubahan suatu kawasan konservasi menjadi taman nasional didasarkan pada aspek ekologis, politis, dan ekonomi. Berdasarkan PP No. 68 tahun 1998 tentang kawasan suaka alam dan kawasan pelestarian alam, suatu kawasan ditunjuk sebagai kawasan taman nasional, apabila telah memenuhi kriteria sebagai berikut:

1) Kawasan yang ditetapkan mempunyai luas yang cukup untuk menjamin kelangsungan proses ekologis secara alami;

2) Memiliki sumberdaya alam yang khas dan unik baik berupa jenis tumbuhan maupun satwa dan ekosistemnya serta gejala alam yang masih utuh dan alami;

3) Memiliki satu atau beberapa ekosistem yang masih utuh;

4) Memiliki keadaan alam yang asli dan alami untuk dikembangkan sebagai pariwisata alam; dan

5) Merupakan kawasan yang dapat dibagi ke dalam zona lain yang karena pertimbangan kepentingan rehabilitasi kawasan, ketergantungan penduduk sekitar kawasan, dan dalam rangka mendukung upaya pelestarian sumber daya hayati dan ekosistemnya, dapat ditetapkan sebagai zona tersendiri.

Berdasarkan sistem zonasi pengelolaannya kawasan taman nasional dapat dibagi atas : (a) zona inti, (b) zona pemanfaatan, (c) zona rimba dan atau zona lain yang ditetapkan menteri berdasarkan kebutuhan pelestarian sumber daya alam hayati dan ekosistemnya.

Tujuan pengelolaan taman nasional menurut Undang-Undang No.5 tahun 1990 pasal 5, adalah untuk melaksanakan fungsi kawasan hutan yang meliputi: (a) Perlindungan sistem penyangga kehidupan; (b) Pengawetan keanekaragaman jenis tumbuhan dan satwa beserta ekosistemnya; dan (c) Pemanfaatan secara lestari sumber daya alam hayati dan ekosistemnya.

Pengelolaan taman nasional harus berdasarkan atas prinsip-prinsip dan keterpaduan ekologi yang bertujuan untuk melindungi dan memelihara keunikan ekosistem dan kekayaan alam serta memanfaatkannya secara lestari tanpa mengabaikan kondisi fisiknya. Berdasarkan PP No. 68 tahun 1998, upaya pengelolaan pada zona inti dilaksanakan dalam bentuk kegiatan: perlindungan dan pengamanan, inventarisasi potensi kawasan, serta penelitian dan pengembangan dalam menunjang pengelolaan. Sedangkan pada zona pemanfaatan dilaksanakan: perlindungan dan pengamanan, inventarisasi 
potensi kawasan, penelitian dan pengembangan dalam menunjang pariwisata alam. Sementara itu pada zona rimba dilaksanakan : perlindungan dan pengamanan, inventarisasi potensi kawasan, penelitian dan pengembangan dalam menunjang pengelolaan, dan pembinaan habitat dan populasi satwa.

Realisasi di lapangan menunjukkan bahwa untuk mencapai optimalisasi fungsi kawasan taman nasional dihadapi dengan berbagai permasalahan/kendala baik yang internal maupun eksternal sehingga memerlukan penanganan secara lebih serius dan terus menerus. Berdasarkan hal tersebut, untuk mencapai optimalisasi fungsi kawasan taman nasional maka harus terbentuk:

1. Pengelolaan taman nasional yang mantap

Untuk menciptakan kondisi pengelolaan taman nasioanal yang mantap upaya yang harus dilakukan antara lain: pendistribusian pegawai yang profesional, sarana dan prasarana yang memadai, dan tata hutan pada kawasan taman nasional harus memuat kegiatan sebagaimana yang tercantum dalam PP No. 34 tahun 2002 meliputi: (a) Penentuan batas-batas kawasan yang ditata; (b) Inventarisasi, identifikasi, dan perisalah kondisi kawasan; (c) Pengumpulan data sosial, ekonomi dan budaya di kawasan dan sekitarnya; (d) Pembagian kawasan ke dalam zonazona; (e) Pemancangan tanda batas zona, dan (f) Pengukuran dan pemetaan.

2. Kualitas Sumber Daya Manusia (SDM) yang memadai

Selain pendistribusian pegawai yang profesional, kualitas SDM pun harus profesional. Artinya pegawai harus memiliki disiplin ilmu yang menunjang dan memiliki latar belakang pendidikan konservasi sumber daya alam dan lingkungan.

3. Pendekatan yang baik terhadap masyarakat sekitar kawasan

Perubahan fungsi kawasan hutan lindung menjadi taman nasional sering kali menghadapi sikap pro dan kontra dari masyarakat sekitar. Dengan demikian diperlukan pendekatan yang lebih intensif berupa kegiatan sosialisasi agar masyarakat mau turut berperan serta dalam pengembangan taman nasional.

4. Membangun tingkat kesadaran masyarakat terhadap kelestarian sumber daya alam taman nasional

Permasalahan yang muncul dalam taman nasional seperti perambahan lahan, pencurian kayu, perburuan liar, dan lain-lain seringkali dilakukan oleh masyarakat sekitar. Oleh karena itu pihak pengelola harus berupaya agar masyarakat tersebut memiliki kesadaran akan pentingnya menjaga kelestarian kawasan hutan dan merasa berkewajiban untuk ikut serta memelihara dan menjaga kawasan hutan dari gangguan dan pengrusakan.

\section{KESIMPULAN}

1. Berdasarkan kondisi fisik dan potensi sumberdaya alamnya kawasan hutan Gunung Ceremai telah menenuhi kriteria untuk dijadikan taman nasional.

2. Bagi masyarakat lokal/masyarakat sekitar kawasan perubahan status kawasan hutan lindung menjadi taman nasional mengakibatkan berkurangnya sumber 


\section{J umal AnalisisKedijakan Kedutanan}

Vo. 3No. 2, Juli 2006: 87-94

pendapatan dari hutan karena akses mereka terhadap kawasan hutan menjadi sangat terbatas.

3. Bagi masyarakat Indonesia secara keseluruhan dan lingkungan, TN merupakan suatu kawasan yang memiliki peran besar sebagai tempat pengawetan keanekaragaman jenis tumbuhan dan satwa, serta pemanfaatan secara lestari sumberdaya alam hayati dan ekosistemnya.

4. Beberapa upaya untuk mencapai optimalisasi fungsi kawasan TN adalah: (i) sistem pengelolaan yang mantap; (ii) meningkatkan kualitas SDM; (iii) terbinanya hubungan yang baik dengan masyarakat sekitar kawasan; dan (iv) membangun tingkat kesadaran masyarakat.

\section{DAFTAR PUSTAKA}

Anonim. 2005. Kawasan Hutan Gunung Ceremai. Website: http//www.kuningan.go.id. Diakses tanggal 12 Mei 2005.

. 2004. Kabupaten Majalengka dalam Angka Tahun 2003. BPS Kabupaten Majalengka. Majalengka.

Handadhari, T. 2004. Dephut Kaji 12 Calon Taman Nasional Baru. Website : http//www.wwf.or.id. Diakses tanggal 13 Mei 2005.

Kepmenhut No. 424 tahun 2004 tentang Perubahan Fungsi Kawasan Hutan Lindung Kelompok Hutan Gunung Ciremai menjadi Taman Nasional.

Peraturan Pemerintah No. 68 tahun 1998 tentang Kawasan Suaka Alam dan Kawasan Pelestarian Alam.

Peraturan Pemerintah No. 34 tahun 2002 tentang Tata Hutan dan Penyusunan Rencana PengelolaanHutan, Pemanfaatan Hutan dan Penggunaan Kawasan Hutan.

Undang-Undang No. 5 tahun 1990 tentang Konservasi Sumber Daya Alam Hayati dan Ekosistemnya.

Undang-Undang No. 41 tahun 1999 tentang Kehutanan. 